\title{
Activation of the U2 snRNA promoter by the octamer motif defines a new class of RNA polymerase II enhancer elements
}

\author{
Masafumi Tanaka, Ueli Grossniklaus, ${ }^{1}$ Winship Herr, and Nouria Hernandez \\ Cold Spring Harbor Laboratory, Cold Spring Harbor, New York 11724
}

\begin{abstract}
The recent discovery that the activation domains of transcriptional activators (e.g., GAL4) from a number of species are interchangeable has led to the concept of a general mechanism for activation of RNA polymerase II genes. We have examined the different activities of the SV40 octamer motif ATGCAAAG in B cells and in HeLa cells in the context of either the $\beta$-globin promoter, a TATA-box-containing mRNA promoter, or the U2 snRNA promoter, which contains a snRNA-specific proximal element. In the context of the $\beta$-globin promoter, the octamer motif is a B-cell-specific enhancer element, whereas it is a ubiquitous enhancer element for the U2 snRNA promoter. The $\mathrm{U} 2$ promoter is unique in that it is not activated by enhancer elements that activate the $\beta$-globin promoter, and a hybrid U2 promoter containing the upstream activating sequence $U_{A A} S_{G}$ is not stimulated by a yeast GAL4 trans-activator. Together, these observations suggest that in the context of the U2 promoter, the octamer motif defines a new class of RNA polymerase II enhancer elements, which bind transcription factors that trans-activate gene expression by a different mechanism than the general mechanism mentioned above. These results are discussed in light of the possibility that the ubiquitous octamer binding protein Oct-1 and the B-cell-specific octamer binding protein Oct-2 are involved in the activation of the U2 and $\beta$-globin promoters, respectively.
\end{abstract}

[Key Words: Oct-1; Oct-2; GAL4 trans-activation; B cells; HeLa cells]

Received October 1, 1988; revised version accepted October 27, 1988.

Recent studies with yeast and mammalian transcriptional activators, such as GAL4, GCN4, and steroid receptors, have revealed a general mechanism for activation of RNA polymerase II transcription (for review, see Ptashne 1988). These trans-activators contain a sequence-specific DNA-binding domain (Brent and Ptashne 1985; Hope and Struhl 1986; Keegan et al. 1986) and a trans-activation domain often characterized by a high concentration of acidic residues ( $\mathrm{Ma}$ and Ptashne 1987a,b; Hope et al. 1988). The specificity of transcriptional control is conferred by the DNA-binding domain, whereas the trans-activation domains of different transactivators seem to be functionally equivalent and can be interchanged (Lech et al. 1988; Sadowski et al. 1988; Struhl 1988; Webster et al. 1988). Thus, a trans-activator such as GAL4 can stimulate transcription from various RNA polymerase II promoters in cells from species as divergent as yeast, animals, and plants, provided that the promoter contains an appropriate DNA-binding site, in this case the GAL1-GAL10 upstream activating sequence $\mathrm{UAS}_{\mathrm{G}}$ (Fischer et al. 1988; Kakidani and Ptashne 1988; Ma et al. 1988; Struhl 1988; Webster et al. 1988). Indeed, in mammalian cells the $\mathrm{UAS}_{\mathrm{G}}$ has the properties

${ }^{1}$ Present address: Biocentre, University of Basel, Basel, Switzerland. of an enhancer in the presence of GAL4 (Webster et al. 1988).

A common mechanism for activation of transcription is consistent with results obtained from a genetic analysis of the SV40 enhancer. These studies have shown that the SV40 enhancer contains at least three independent elements, called A, B, and C, which can compensate functionally for one another by duplication (Herr and Clarke 1986; Ondek et al. 1987; Schirm et al. 1987). More recently, the SV40 A and B elements were shown to be bipartite, being composed of interchangeable subunits called enhansons (for basic unit of enhancer structure; Ondek et al. 1988). The ability of different enhancer elements to compensate functionally for one another suggested that the factors responsible for their function activate transcription through a common mechanism (Herr and Clarke 1986).

If the mechanism of transcription activation is general, however, the octamer motif presents a paradox. This motif is found in the promoter region of heavy- and light-chain immunoglobulin genes, in the heavy-chain ( $\mathrm{IgH}$ ) enhancer, and in the SV40 promoter (Falkner and Zachau 1984; Parslow et al. 1984; Falkner et al. 1986). In these promoters and when inserted upstream or downstream of several other mRNA promoters, the octamer motif displays lymphoid-specific activity (Davidson et al. 1986; Gerster et al. 1987; Lenardo et al. 1987; Wirth 
et al. 1987). But the octamer motif also plays a role in non-B cells as an enhancer of snRNA transcription (Mattaj et al. 1985; Mangin et al. 1986; Ares et al. 1987; for review, see Dahlberg and Lund 1988) and as a cellcycle-regulated proximal element in the human histone H2B gene (Harvey et al. 1982; LaBella et al. 1988). These different patterns of lymphoid-specific and ubiquitous transcriptional regulation parallel the expression of two proteins that bind indistinguishably to the octamer motif (Landolfi et al. 1986; Staudt et al. 1986; Rosales et al. 1987, Scheidereit et al. 1987). One of these proteins is expressed predominantly in lymphoid cells of the B lineage, whereas expression of the second is ubiquitous (Landolfi et al. 1986; Singh et al. 1986; Staudt et al. 1986; Rosales et al. 1987; Scheidereit et al. 1987; Sturm et al. 1988). The B-cell-specific octamer binding protein, NF-A2 (Staudt et al. 1986) or OTF-2 (Scheidereit et al. 1987), is the product of the oct-2 gene and referred to here as Oct-2, whereas the ubiquitous octamer binding protein, variously referred to as NF-Al (Staudt et al. 1986), OTF-1 (Fletcher et al. 1987), NFIII (Pruijn et al. 1986; O'Neill and Kelly 1988), and OBP100 (Sturm et al. 1987 ), is the product of the oct-1 gene and referred to here as Oct-1 (see Clerc et al. 1988; Sturm et al. 1988). The differential expression of Oct- 2 and Oct-1, however, does not explain how these factors discriminate in activating different promoters. If trans-activation domains are interchangeable, why are the immunoglobulin promoters not trans-activated, as are snRNA promoters, by the ubiquitous octamer binding factor in nonlymphoid cells? The answer may lie, in part, in the structure of the snRNA promoters.

The U1 and U2 snRNA genes encode short, nonpolyadenylated RNAs that are involved in pre-mRNA splicing. In addition to being very highly transcribed by RNA polymerase II (Frederiksen et al. 1978; Gram Jensen et al. 1979; Murphy et al. 1982), these genes share a number of unusual characteristics when compared to mRNA-encoding genes. First, the promoters lack a TATA box and instead contain a snRNA-specific proximal element located $40-60$ bp upstream of the transcriptional start site (Skuzeski et al. 1984; Ares et al. 1985; Ciliberto et al. 1985; Mattaj et al. 1985; Mangin et al. 1986; Murphy et al. 1987; Hernandez and Lucito 1988). Second, $3^{\prime}$ end formation of snRNAs occurs by an unusual mechanism that requires a signal, called the $3^{\prime}$ box, located downstream of the snRNA-coding region (Hernandez 1985; Yuo et al. 1985; Ciliberto et al. 1986; Neuman de Vegvar et al. 1986; Ach and Weiner 1987). Although necessary, the $3^{\prime}$ box is not sufficient for correct $\mathrm{U} 1$ or $\mathrm{U} 23^{\prime}$ end formation, because if the promoter regions of these genes are replaced by promoters that direct transcription of mRNAs (e.g., $\beta$-globin or adenovirus major late promoters|, the $3^{\prime}$ box is ignored and mature RNAs extend to a polyadenylation site inserted downstream (Hernandez and Weiner 1986; Neuman de Vegvar et al. 1986). Moreover, even with a fully functional U2 promoter, only correctly initiated transcripts terminate properly. Transcripts that initiate at cryptic promoters upstream in the vector and read through the
U2 gene ignore the $3^{\prime}$ box and become polyadenylated (Hernandez and Lucito 1988). Extensive mutagenesis of the U2 promoter region has shown that multiple U2 promoter elements, including the enhancer, are involved in directing an RNA polymerase II transcription complex that can recognize the $3^{\prime}$ box (Hernandez and Lucito 1988 ).

Although it has been known for some time that enhancer elements containing the octamer motif lie upstream of snRNA promoters (Mattaj et al. 1985; Mangin et al. 1986; Murphy et al. 1987), it is not clear whether these enhancers are dedicated specifically to snRNA transcription. Experiments in which the Xenopus (Ciliberto et al. 1987) or human (Dahlberg and Schenborn 1988) U1 enhancers were placed upstream of the SV40 early promoter suggest that the U1 enhancer cannot activate transcription from mRNA-encoding genes. It has been reported, however, that the SV40 enhancer can activate U2 transcription (Mangin et al. 1986), although in some constructs, insertion of the SV40 enhancer region also resulted in activation of aberrantly initiated transcripts (Hernandez and Weiner 1986). The SV40 enhancer contains multiple redundant elements (Herr and Clarke 1986; Zenke et al. 1986), as well as two octamerrelated motifs (Falkner and Zachau 1984; Sturm et al. 1987); therefore, it is not evident which of the SV40 enhancer elements or octamer motifs was responsible for specific U2 transcriptional activation.

To understand the nature of the lymphoid-specific and ubiquitous enhancer activities of the octamer motif, we have studied the ability of different versions of the SV40 $B$ element to enhance expression of the human $\beta$-globin and U2 snRNA promoters in HeLa cells and B cells. The B element contains a tandemly repeated 9-bp sph motif and a 7 - out of 8 -bp match to the octamer consensus formed by the junction of the two sph motifs (see Fig. 1A). In HeLa cells, the ability of the B element to enhance $\beta$-globin expression is dependent on the sph motifs, whereas the octamer motif is inactive (Davidson et al. 1986; Zenke et al. 1986; Ondek et al. 1987, 1988). Here, we introduce sets of point mutations into the $B$ element that suppress sph motif or octamer motif function independently or together. Functional tests of multimerized wild-type and mutant B elements show that the sph motifs and the SV40 A and C enhancer elements are unable to activate the $U 2$ promoter. In contrast, the octamer motif, which in the context of the $\beta$-globin promoter is a B-cell-specific enhancer element, can enhance the U2 snRNA promoter in either B cells or HeLa cells. Nevertheless, the $\beta$-globin promoter can be activated by the octamer motif in HeLa cells if the herpes simplex virus (HSV) gene product VP16 is present. These patterns of activity suggest that the lymphoid octamer binding protein and the ubiquitous octamer binding protein in the presence of VP16 can activate transcription by a mechanism analogous to that used by the GAL4 acidic trans-activating domain. These results also suggest that in contrast, the ubiquitous octamer binding protein stimulates transcription of snRNA genes by a different mechanism. Consistent with this hypothesis, 
we show that a GAL4 trans-activator capable of activating the $\beta$-globin promoter does not activate the $U 2$ promoter.

\section{Results}

Figure 1A shows the position of the three SV40 enhancer elements A, B, and C, with respect to the SV40 early promoter. It also shows the sequence of the B-element region along with the position of the two sph motifs (sphII and sphI) and the 7-out of 8-bp match (ATGCAAAG) to the octamer consensus sequence (ATGCAAAT). Despite the single base difference with the consensus octamer motif, the SV40 octamer motif is involved in activation of transcription in B cells (Davidson et al. 1986) and binds to both the lymphoid and ubiquitous octamer binding factors (Rosales et al. 1987). In addition, we have shown that Oct-1 (OBP100) binds with only slightly reduced affinity to this SV40 octamer

Figure 1. (A) The first line shows the SV40 early promoter region with a single copy of the 72-bp element, two perfect and one imperfect 2l-bp repeats, the AT-rich TATA-like element, the origin of replication (ori), and the early transcriptional start sites (wavy arrow). Below, the locations of the three SV40 enhancer elements A, B, and C are indicated. The third line shows the sequence of the B element region; the sph motifs are underlined, and the octamer motif at the junction of the two sph motifs is bracketed. $(B)$ Sequence of the wild-type and mutant B20 synthetic enhancer repeats. When the B20 oligonucleotides are reiterated, the boxed nucleotides constitute $X h o I$ restriction sites. The changes introduced by the double point mutations $d p m 2, d p m 7$, and $d p m 8$ are indicated. $(C)$ Structure of the $\beta$ globin and $\mathrm{U} 2$ expression vectors. The plasmid $\mathrm{p} \beta \mathrm{e}^{-}$is as described previously (Ondek et al. 1987) and contains the human $\beta$-globin gene (stippled box) inserted into the polylinker (hatching) of pUC119 (thin line). The $\beta$-globin transcriptional start site is depicted by a wavy arrow. The synthetic enhancers consist of six wild-type or mutant B20 repeats (arrows) separated by $X h o l$ restriction sites (boxes), and were inserted either into the SmaI restriction site, 143 bp upstream of the $\beta$-globin transcriptional start site in the + orientation, or into the $S p h I$ restriction site, $2.2 \mathrm{~kb}$ downstream (or $3.3 \mathrm{~kb}$ upstream) of the start site in the (-) orientation. The plasmid pU2/ -198 (Hernandez and Lucito 1988) contains a hybrid U2 gene inserted between the EcoRI and HindIII sites of pUC13 (thin line). The hybrid gene consists of (1) a human U2 promoter (thick black box) deleted to position -198 upstream of the cap site and therefore lacking the U2 enhancer, (2) the first 28 bp of the U2coding region (open box), (3) a 137-bp fragment derived from the rabbit $\beta$-globin gene and cloned in the reverse orientation (wavy line), (4) the last $6 \mathrm{bp}$ of the U1-coding region (arrowhead), (5) 90 bp of U1 3'-flanking sequences (thin black box) containing the $3^{\prime}$ box. This is followed by a fragment derived from adenovinus 2 and carrying the L3 polyadenylation site (white box) and a fragment carrying the SV40 origin of replication (hatched box). The U2 transcriptional start site is depicted by a wavy arrow. The synthetic enhancers were inserted at position - 198, upstream of the transcriptional start site in the + orientation. $(D)$ Structure of the human U2 promoter. The locations of the enhancer, which contains an Spl-binding site (SP1) adjacent to an octamer motif (OCTA), as well as the proximal element (PE) are indicated. motif, compared to the perfect histone $\mathrm{H} 2 \mathrm{~B}$ octamer motif (Baumruker et al. 1988). These results and those described below indicate that this SV40 octamer-related motif is a bona fide octamer element. The activity of a second, more degenerate, octamer motif (ATCTCAAT), which flanks the first octamer motif and is also a binding site for Oct-1 (Sturm et al. 1987; Baumruker et al. 1988), has not been analyzed in these studies.

Figure 1B shows the structure of the wild-type and mutant 24-bp oligonucleotide repeats that we used to study the activities of the octamer motif and overlapping sph motifs. Each oligonucleotide repeat contains 18 bp of the wild-type or mutant SV40 sequence separated by 6-bp XhoI recognition sites. Fortuitously, the AG dinucleotide of the XhoI recognition sequence CTCGAG extends the wild-type SV40 enhancer sequence by $2 \mathrm{bp}$. We therefore refer to these elements as B20. As shown below and described previously (Ondek et al. 1987), the AG dinucleotide sequence is not essential for the activity of the B element. The three sets of double point



B

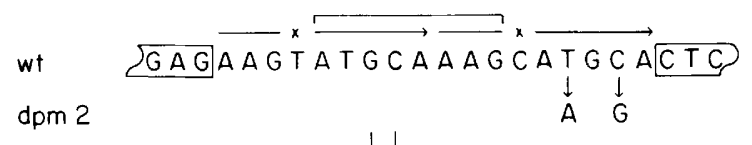

dpm 7

dpm 8



C

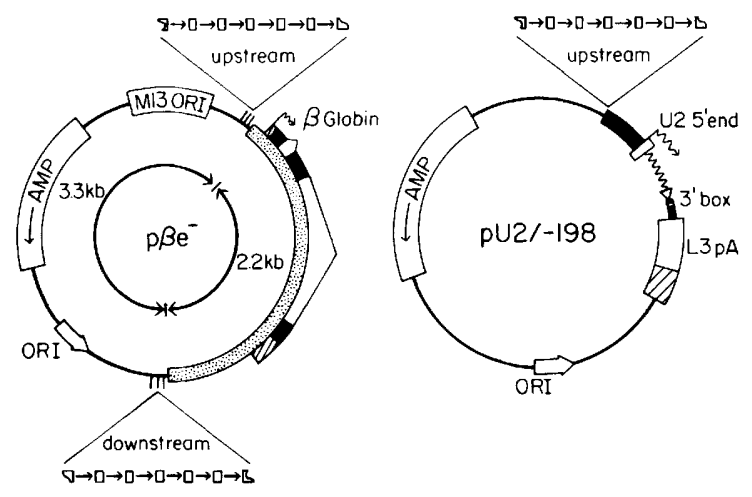

D

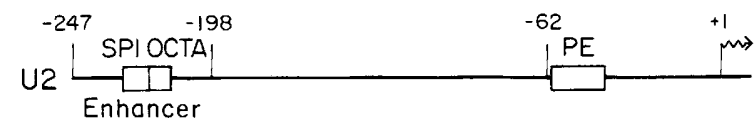


mutations $(d p m)$ shown in Figure 1B were designed to discriminate between the activities of the sph motifs and the octamer motif. The $d p m 2$ mutation lies within the sphI motif and nullifies the ability of oligomerized $B$ element constructs to enhance transcription of the $\beta$ globin gene in HeLa cells (Ondek et al. 1987, 1988) but does not affect binding of Oct-1 to the octamer motif (Sturm et al. 1987). The $d p m 7$ mutation was designed to inactivate the octamer motif but not affect the activity of the sph motifs; we used as a guide a similar mutation (pA24; Zenke et al. 1986), which affects expression of the SV40 promoter more in B cells than in HeLa cells (Davidson et al. 1986). The $d p m 7$ mutation hinders, but does not abolish, Oct-1 binding to the octamer motif in a gel retardation assay $(R$. Sturm and $T$. Baumruker, unpubl.). The dpm8 mutation lies within the sphII motif and is analogous to the $d p m 2$ mutation within the sphI motif. But unlike $d p m 2$, this mutation interferes strongly with Oct-1 binding to the B element octamer motif (Sturm et al. 1987) and inactivates the B element under all conditions assayed (see below). Thus, in the studies described below, the wild-type element displays both sph and octamer motif activities, the $d p m 2$ and $d p m 7$ mutants display octamer and sph motif activity, respectively, whereas the $d p m 8$ mutant is inactive.

To test the enhancer (distal) and upstream promoter (proximal) activities of this set of four elements in the context of an mRNA-encoding gene, six tandem copies were inserted into the human $\beta$-globin expression vector $\mathrm{p} \beta \mathrm{e}^{-}, 2.2 \mathrm{~kb}$ downstream and also $143 \mathrm{bp}$ upstream of the $\beta$-globin transcriptional start site (see Fig. $1 \mathrm{C}$ ). To test snRNA promoter activation, the same set of tandem elements were cloned 198 bp upstream of the U2 transcriptional start site in the human $\mathrm{U} 2$ expression vector pU2/-198, replacing the U2 enhancer element, which itself contains juxtaposed binding sites for octamer and Spl-like factors (Mangin et al. 1986; Ares et al. 1987; Janson et al. 1987), as indicated in Figure 1D. The activity of the various constructs was assayed by transient expression in HeLa cells and NS-1 cells, the latter of which are nonimmunoglobulin-secreting murine B cells. Levels of promoter activation were gauged by RNase protection of antisense RNA probes and normalization to expression of a cotransfected human $\alpha$-globin gene, which served as an internal reference for transfection efficiency. Below we first describe the ability of the different oligomerized elements to activate the $\beta$-globin gene in the NS-1 B cell line and then compare the ability of these constructs to activate the $\beta$-globin and U2 promoters in HeLa cells.

\section{The SV40 octamer (decamer) motif is sufficient to} enhance transcription of the $\beta$-globin gene in $B$ cells

Figure 2 shows the result of transient expression in the NS-1 B cell line of $\beta$-globin constructs containing the matched set of B elements. The reference $\alpha$-globin-protected fragment (labeled $\alpha$ ) is 132 nucleotides long and maps the 5 ' end of the $\alpha$-globin RNA. Correctly initiated $\beta$-globin transcripts protect a 350 -nucleotide-long frag-

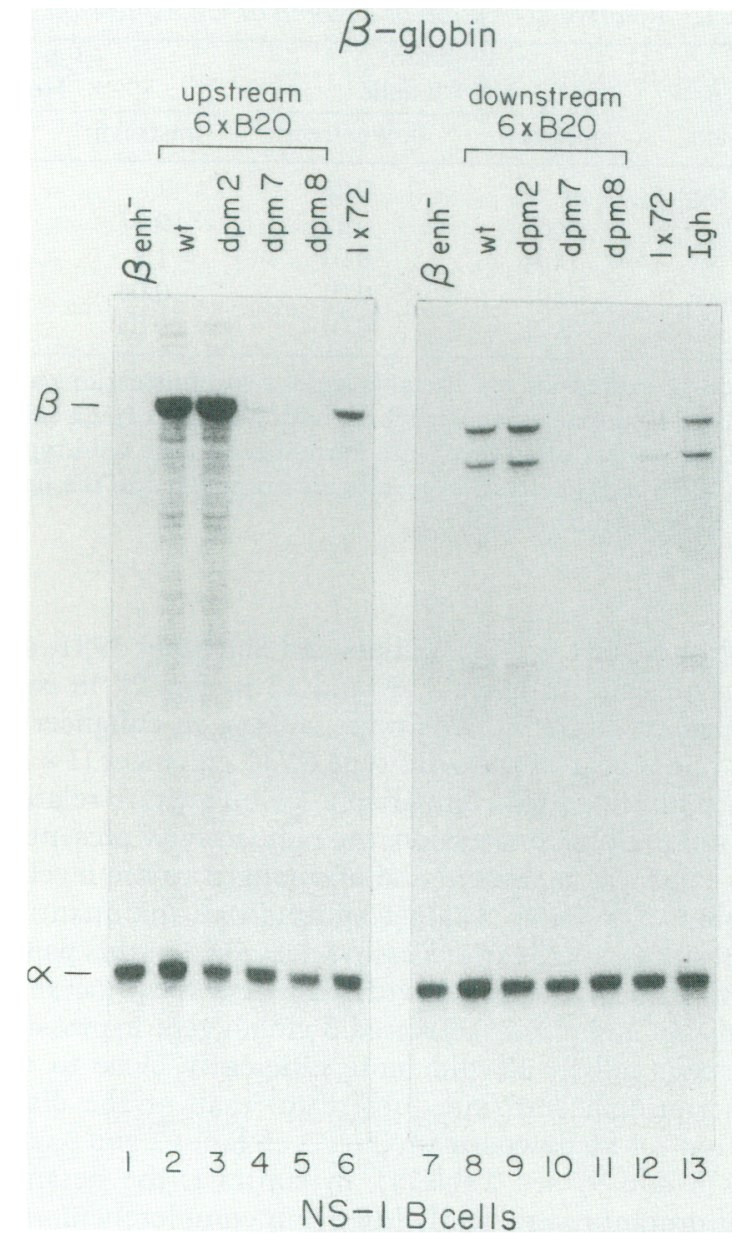

Figure 2. Activation of the $\beta$-globin promoter in NS-1 B cells. $\mathrm{p} \mathrm{Be}^{-}$derivatives were transfected into NS-1 B cells, together with the plasmid $\pi$ SVHP 2 (Treisman et al. 1983) as an internal reference. Cytoplasmic RNA was analyzed by RNase protection mapping using a mixture of two probes, one mapping transcripts derived from the $\beta$-globin gene ( $\beta 350$ probe) and the other mapping transcripts derived from the $\alpha$-globin reference gene ( $\alpha 132$ probe). Bands corresponding to correctly initiated $\beta$-globin $(\beta)$ and $\alpha$-globin $|\alpha|$ transcripts are indicated. The $\beta$-globin constructs used in the transfection were $p \beta e n h-$ (lanes 1 and 7), $\mathrm{p} \beta 6 \times \mathrm{B} 20^{+/-143}$ (lane 2), $\mathrm{p} \beta 6 \times \mathrm{B} 20 \mathrm{dpm} 2+/-143$

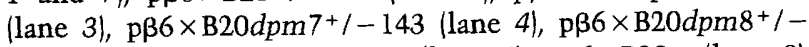
143 (lane 5), $\mathrm{p} \beta 1 \times 72^{+} /-143$ (lane 6), $\mathrm{p} \beta 6 \times \mathrm{B} 20^{-}$(lane 8), $\mathrm{p} \beta 6 \times \mathrm{B} 20 \mathrm{dpm} 2^{-}$(lane 9), $\mathrm{p} \beta 6 \times \mathrm{B}^{-02 d p m 7^{-}}$(lane 10), $\mathrm{p} \beta 6 \times \mathrm{B} 20 \mathrm{dpm} 8^{-}$(lane 11$), \mathrm{p} \beta 1 \times 72^{-}$(lane 12), and $\mathrm{p} \beta$ Igh - (lane 13 ), a $\mathrm{p} \beta \mathrm{e}^{-}$derivative containing the mouse IgH enhancer inserted downstream of the transcriptional start site. The structures of the different constructs are indicated above the lanes. The $6 \times \mathrm{B} 20 \mathrm{dpm} 2$ construct is active in B cells, in contrast to the $6 \times \mathrm{B} 17 \mathrm{dpm} 2$ construct described previously (Ondek et al. 1987). The lack of octamer motif activity in the $6 \times \mathrm{B} 17 \mathrm{dpm} 2$ construct in B cells is a peculiarity of this particular synthetic enhancer.

ment (labeled $\beta$ ) from RNase digestion. In this assay, $\beta$ globin transcripts that initiate upstream of the correct start site generally appear as a slightly shorter fragment because of splicing to a cryptic splice acceptor $30 \mathrm{nu}$ cleotides downstream of the bona fide $\beta$-globin tran- 
Table 1. Relative activation of $\beta$-globin or $U 2$ expression by wild-type and mutant $6 \times B 20$ repeats

\begin{tabular}{|c|c|c|c|c|c|c|c|c|}
\hline \multirow{2}{*}{$\begin{array}{l}6 \times \mathrm{B} 20 \\
\text { enhancer }\end{array}$} & \multicolumn{2}{|c|}{$\begin{array}{c}\beta \text {-globin }{ }^{\mathrm{a}} \\
\text { NS-1 B cells }\end{array}$} & \multicolumn{2}{|c|}{$\begin{array}{c}\beta \text {-globin }{ }^{\mathbf{a}} \\
\text { HeLa }\end{array}$} & \multicolumn{2}{|c|}{$\begin{array}{l}\mathrm{U}^{\mathrm{b}} \\
\mathrm{HeLa}\end{array}$} & \multicolumn{2}{|c|}{$\begin{array}{c}\beta \text {-globinc } \\
\text { HeLa }+ \text { VP16 }\end{array}$} \\
\hline & upstream & downstream & upstream & downstream & readthrough & $\mathrm{U} 25^{\prime}$ & upstream & downstream \\
\hline Wild type & 1 & 0.08 & 1 & 0.5 & 1 & 1 & 1.2 & N.D.d \\
\hline$d p m 2$ & 2.30 & 0.13 & 0.07 & 0.04 & 0.2 & 2.3 & 0.8 & 0.07 \\
\hline$d p m 7$ & 0.04 & 0.01 & 1.4 & 0.7 & 1.5 & 0.1 & 1.1 & N.D. \\
\hline$d p m 8$ & 0.01 & 0.01 & 0.04 & 0.04 & 0.09 & 0.01 & 0.04 & N.D. \\
\hline None & 0.01 & 0.01 & 0.05 & 0.05 & 0.15 & 0.01 & 0.06 & 0.06 \\
\hline
\end{tabular}

a Levels of expression are the average of two transfections and were within $\pm 20 \%$. The $\beta$-globin results are normalized to the wildtype $6 \times$ B20 upstream construct for both NS-1 and HeLa cells.

b The U2 transcription levels are normalized to the wild-type construct in each case.

c The VP16 trans-activation results are normalized to the upstream $6 \times$ B20 wild-type HeLa cell sample without VP16.

d (N.D.) Not determined.

scriptional start site (de Villiers and Schaffner 1981; see the extra band in lanes 8,9 , and 13 in Fig. 2). In each experiment, $\beta$-globin constructs lacking an enhancer or with one repeat of the wild-type SV40 enhancer $(1 \times 72)$ were transfected for comparison. To quantitate relative levels of $\beta$-globin expression, the radioactivity present in each band was measured and normalized to the level of $\alpha$-globin expression. Table 1 summarizes the quantitative results for the various assays described in this paper.

Both of the constructs with wild-type SV40 octamer motifs (wt and dpm2) activated $\beta$-globin gene expression in $B$ cells, albeit 12 -fold more efficiently close to the transcriptional start site (upstream) than at the distal position $2.2 \mathrm{~kb}$ downstream (Fig. 2, cf. lanes 2 and 3 with lanes 8 and 9; see Table 1). In contrast, the octamer motif mutants were nearly $(d p m 7)$ or completely $(d p m 8)$ inactive in either position (Fig. 2, lanes 4, 5, 10, and 11). These results are consistent with previous reports. Schirm et al. (1987) and Ondek et al. (1987) showed that similar segments of the SV40 enhancer were active as enhancers in B cells, and Davidson et al. (1986) showed that in its natural context, mutations within the octamer motif affected B-cell function of the SV40 early promoter.
However, these previous studies did not address whether the octamer motif can activate transcription in B cells autonomously or whether it is part of a bipartite element, requiring additional flanking sequences. Indeed, the B cell-specific activity of the SV40 octamer motif could be conferred by an adjacent $B$ cell-specific enhancer. To test this possibility, we assayed the $\beta$ globin enhancer (distal) activity of a large number of mutants of the B20 repeat in both NS-1 and HeLa cells. As shown in Table 2, except for one particular case $(d p m 4)$ in which enhancer activity was partially abolished, only mutations within the octamer motif itself$d p m 7, d p m 8$, and $d p m 11$-affected B cell enhancer function, and these all abolished activity. These results suggest that the activity of the SV40 B-element region in $B$ cells rests with the octamer motif alone. Therefore, the octamer motif is an example of an enhanson that can enhance transcription independently of an immediately adjacent enhanson. It may be significant that as a solitary enhanson the octamer motif displays considerably more activity when positioned in a promoter proximal position, whereas the sph enhansons, which work as a pair (Ondek et al. 1988), are relatively unaffected by distance in this assay (see Table 1).

Table 2. Effect of multiple point mutations within the B20 repeat on downstream activation of $\beta$-globin expression

\begin{tabular}{|c|c|c|c|}
\hline $\begin{array}{l}6 \times \mathrm{B} 20 \\
\text { enhancer }\end{array}$ & \begin{tabular}{c}
\multicolumn{2}{c}{ Octamer } \\
GAGAAGT \\
CATGCACTC
\end{tabular} & $\begin{array}{l}\text { NS-1 } \\
\text { B cells }\end{array}$ & $\mathrm{HeLa}^{\mathrm{a}}$ \\
\hline $\begin{array}{l}\text { Wild type } \\
d p m 2 \\
d p m 16 \\
d p m 4 \\
d p m 7 \\
d p m 8 \\
d p m 11 \\
\text { sphI/sphI } \\
\text { sphII/sphII } \\
d p m 13 \\
d p m 2 / 13 \\
d p m 2 / 17 \\
\text { None }\end{array}$ & 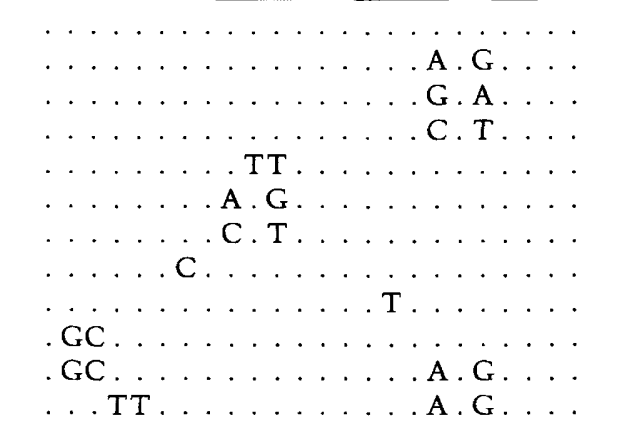 & $\begin{array}{l}+ \\
+ \\
+ \\
+1- \\
- \\
- \\
- \\
+ \\
+ \\
+ \\
+ \\
+\end{array}$ & $\begin{array}{l}+ \\
- \\
- \\
+1- \\
+ \\
- \\
- \\
- \\
+ \\
+ \\
- \\
-\end{array}$ \\
\hline
\end{tabular}

a $|+| 80-160 \% ; 1+/-|30 \% ;|-\mid<12 \%$ the level of wild-type $6 \times \mathrm{B} 20$ expression. 
The octamer motif activates the U2 promoter but not the $\beta$-globin promoter in HeLa cells

Figure 3 shows a comparison of the activity in HeLa cells of the wild-type and mutant oligomerized SV40 B element constructs when positioned upstream or downstream of the $\beta$-globin gene and when replacing the natural U2 enhancer. As in NS-1 cells, the wild-type $6 \times \mathrm{B} 20$ construct activates $\beta$-globin expression in HeLa cells (Fig. 3A, lanes 2 and 8 ), whereas the $d p m 8$ mutant fails to enhance $\beta$-globin expression (lanes 5 and 11). However, in clear contrast to the results in NS-1 cells, the $d p m 2$ mutant with a wild-type octamer sequence displays no activity in HeLa cells, either proximal or distal to the $\beta$-globin promoter (lanes 3 and 9). Moreover, the octamer mutant $d p m 7$, which is inactive in B cells, is completely active in HeLa cells (lanes 4 and 10). This result shows succinctly that the activity of the short 20-bp B-element sequence in NS-1 and HeLa cells is the result of two separable but overlapping cis-acting elements.

Figure 3B shows the relative activity of the oligomerized $\mathrm{B}$ element constructs in the context of the U2 promoter. An important aspect of the U2 expression assay is that we monitor two transcriptional activities simultaneously-correctly initiated transcripts derived from the U2 promoter (U2 $\left.5^{\prime}\right)$ and readthrough transcripts derived from cryptic promoters located upstream of the correct start site (readthrough). These two types of transcripts are qualitatively different because only transcripts that initiate at the correct U2 start site terminate at the downstream 3' box (see Fig. 1C); the readthrough transcripts are 'mRNA-like' in that they continue to the downstream adenovirus L3 polyadenylation site (see Fig. 1C; Hernandez and Lucito 1988). Thus, these two transcripts are the result of distinctly different transcriptional complexes and, as shown here, respond differently to the multimerized enhancer elements.

Consistent with its broad activity, the wild-type B element (Fig. 3B, lane 2) activates both the correctly initiated $\mathrm{U} 2$ transcripts and the readthrough transcripts, whereas the $d p m 8$ enhancer activates neither transcript (lane 5) and thus resembles the enhancerless U2 control template (lane 1). Activation of the U2 promoter by the wild-type B-element oligomer shows a subtle but important difference compared with the wild-type U2 enhancer control (lane 6): The ratio of readthrough to correctly initiated U2 transcripts is $>10$-fold higher in the $6 \times \mathrm{B} 20$ construction. This difference is accentuated all the more dramatically by the activity of the $d p m 2$ and $d p m 7$ mutants. The $d p m 2$ construct, which contains a wild-type octamer motif and does not enhance $\beta$-globin expression effectively in HeLa cells, enhances correctly initiated U2 transcripts but not readthrough transcripts (lane 3) in these cells. In contrast, the dpm7 mutant, which does activate $\beta$-globin expression, only weakly activates correctly initiated U2 RNAs but strongly activates the readthrough transcripts (lane 4). The activities of the U2 constructs in B cells are similar to those observed in HeLa cells, except that the stimulation is weaker (data not shown). To ensure that the different activities of the B element on the U2 and $\beta$-globin promoters were not due to differences in the expression vectors, we transferred the $\beta$-globin promoter with the synthetic enhancers at position -143 into the $\mathrm{U} 2 \mathrm{ex}-$ pression vector, replacing only the U2 promoter sequences. The results obtained with these constructs were similar to those described above for the $p \beta$ constructs. The activities of the B element oligomers are summarized in Figure 3C.

To show that the inability of $6 \mathrm{xB} 20 \mathrm{dpm} 7$ to enhance expression of the $\mathrm{U} 2$ promoter efficiently is a general property of enhancer elements that can activate $\beta$-globin expression, we assayed the activity of the SV40 A and C enhancer elements in the $\mathrm{U} 2$ expression vector. As shown in Figure 3B, these enhancers fail to activate the U2 promoter at all (cf. lanes 8 and 9 with lane 11). In comparison, a different synthetic enhancer $(6 \times B 17)$, which contains the octamer motifs spaced differently, still activates U2 transcription (lane 10). The $6 \times \mathrm{B} 17$ synthetic enhancer also activated U2 transcription when inserted downstream of the gene, although much less efficiently (not shown). Thus, the octamer motif is clearly unique in its ability to activate the $\mathrm{U} 2$ promoter and inability to activate the $\beta$-globin or $\mathrm{U} 2$ readthrough transcripts in HeLa cells.

\section{A GAL4 acidic domain does not activate the U2 promoter}

Recent studies have shown that the yeast trans-activator GAL4 can activate the MMTV (Kakidani and Ptashne 1988), HSV-1 thymidine kinase, rabbit $\beta$-globin, and adenovirus major late promoters (Webster et al. 1988) in mammalian cells, provided GAL4 DNA-binding sites are inserted into the test promoter constructs. A GAL4 mutant that retains the DNA-binding domain (the amino-terminal 147 amino acids) but lacks the sequences required for transcriptional activation in yeast does not activate transcription in mammalian cells (Kakidani and Ptashne 1988). Either of two separable transactivation domains of GAL4 (called I and II), both of which are characterized by a high concentration of acidic residues (Ma and Ptashne 1987a), can enhance transcription in mammalian cells (Kakidani and Ptashne 1988). Thus, these acidic domains can indiscriminately activate a variety of TATA-box-containing mRNA promoters. Because mammalian enhancer elements are unable to activate the U2 promoter, we asked whether a functional GAL4 trans-activator would also be incapable of activating $\mathrm{U} 2$ transcription.

The GAL4 upstream activating sequence $\left(\mathrm{UAS}_{\mathrm{G}}\right)$ was cloned upstream of the human $\beta$-globin and U2 promoters (see Fig. 1C), and expression of $\beta$-globin and $U 2$ reporter transcripts was assayed in the presence or absence of the functional GAL4 deletion mutant GAL4 $(1-147,768-881)$, expressed by the plasmid pAG236, or the nonfunctional mutant GAL4(1-147), expressed by pAG147 (Kakidani and Ptashne 1988). The functional 


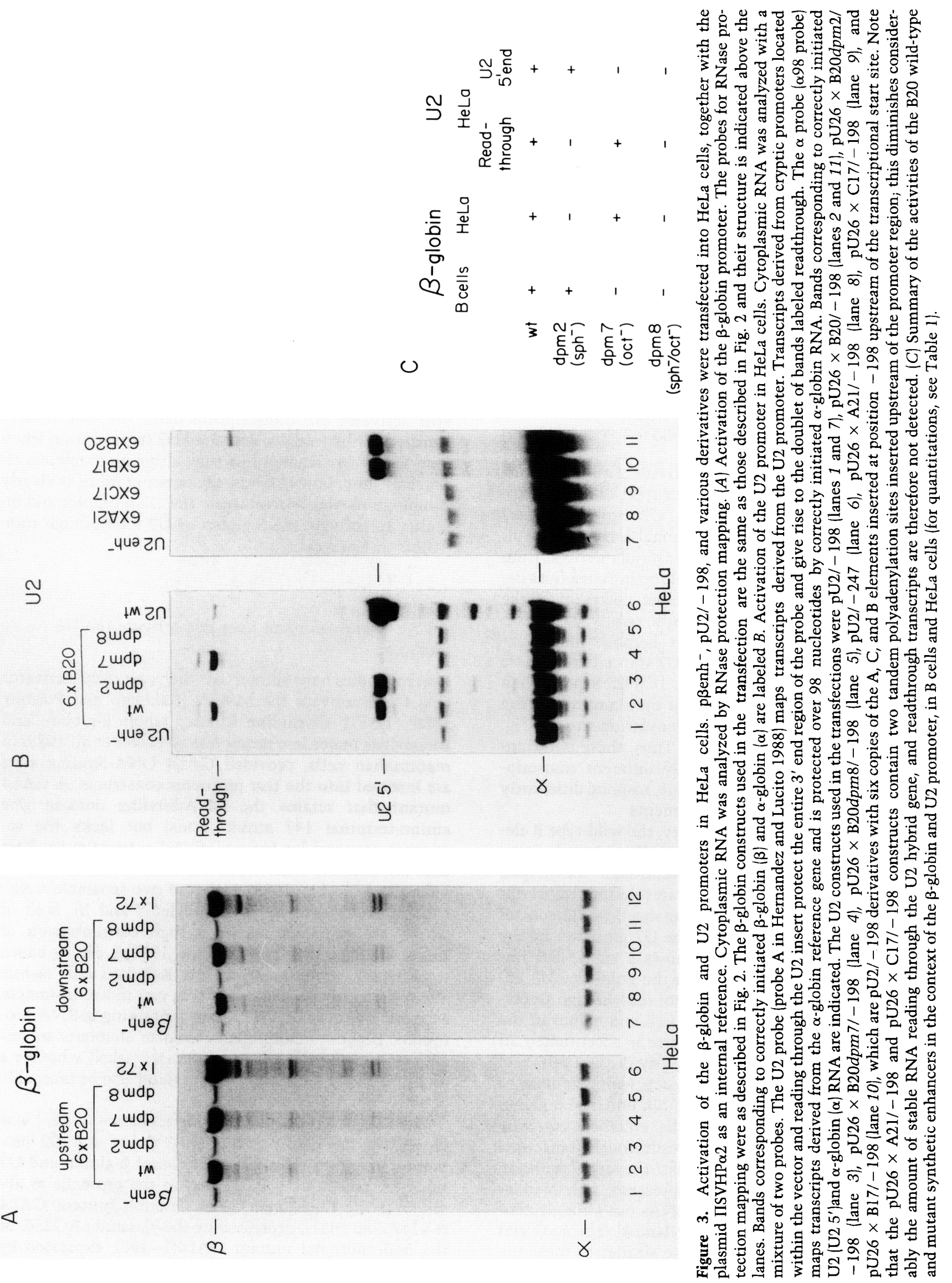


GAL4 derivative contains activation domain II fused to the DNA-binding domain, whereas GAL4(1-147) retains the DNA-binding domain but lacks both activation domains I and II. Figure 4 shows the results of one such experiment in HeLa cells. Consistent with previous studies (Kakidani and Ptashne 1988), cotransfection of pAG236 does not activate the human $\beta$-globin promoter in the absence of a GAL4-binding site (cf. lanes 1 and 2). Unexpectedly, simple insertion of the $\mathrm{UAS}_{\mathrm{G}}$ element upstream of the $\beta$-globin promoter slightly reduced expression from this promoter (cf. lanes 1 and 3). However, as expected, cotransfection of the GAL4(1-147) DNAbinding domain had no discernible effect on expression (lane 4), whereas the functional GAL4 activator stimulated $\beta$-globin expression (lane 5).

In contrast, stimulation of transcription from a U2 promoter containing the $\mathrm{UAS}_{\mathrm{G}}$ could not be observed in the presence of the functional GAL4 activator (Fig. 4, cf. lanes 9 and 10; even on very long exposures of these protection assays in which the residual level of enhancerless transcription could be detected, there was no evident stimulation by the GAL4 activator). Significantly, although the correctly initiated U2 transcripts were not activated, the readthrough transcripts that are stimulated by the SV40-derived enhancer elements were also enhanced by the GAL4 activator (lane 10) but not by the GAL4 DNA-binding domain alone (lane 9). This result serves as an important control showing that the GAL4 activator was functional in this assay. To show that the lack of $\mathrm{U} 2$ stimulation was not an artifactual $\mathrm{UAS}_{\mathrm{G}}$ po-

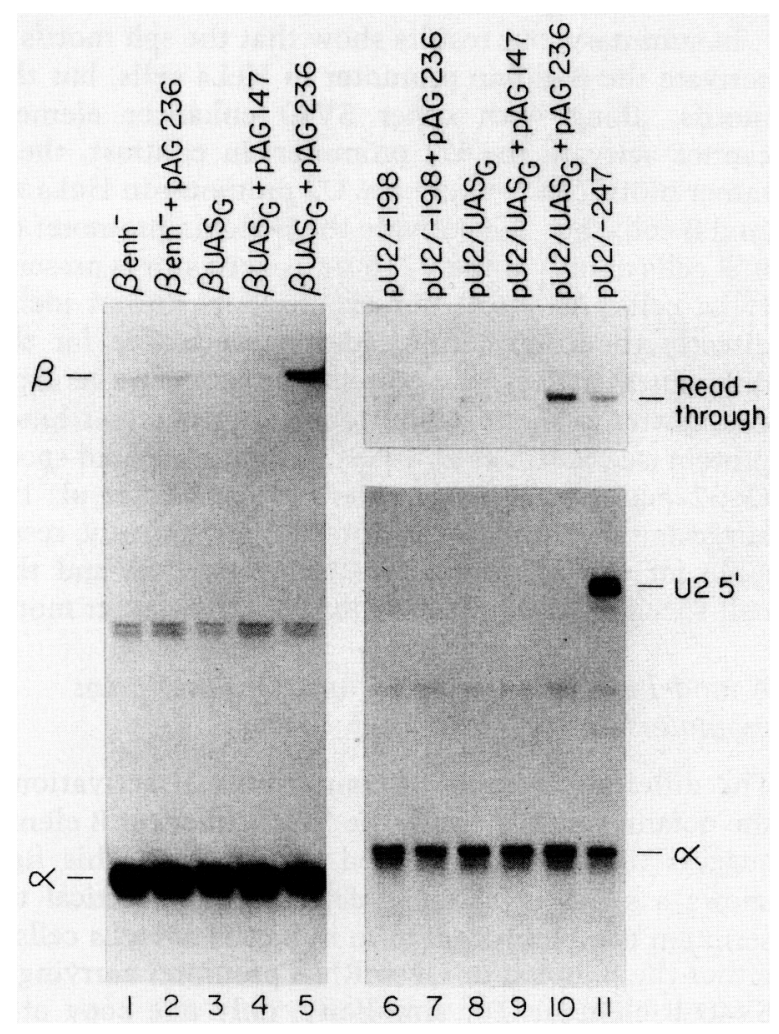

sition effect, U2 expression was also assayed with the $\mathrm{UAS}_{\mathrm{G}}$ positioned immediately upstream of the U2 proximal element (at -62 ); this construct also failed to be activated by the GAL4 activator (data not shown). Activation of the $\mathrm{U} 2$ and $\beta$-globin $\mathrm{UAS}_{\mathrm{G}}$ constructs by GAL4 was also tested in B cells, with similar results as those described above (not shown). Because the GAL4 activator does not activate the U2 promoter, which is transcribed by RNA polymerase II, we conclude that the GAL4 activator is not a universal RNA polymerase II activator.

The octamer motif can activate the $\beta$-globin promoter from a proximal but not distal position in the presence of the HSV trans-activator VP16 in HeLa cells

The HSV-encoded late gene product VP16 (Vmw65) is a trans-activator of the HSV immediate early (IE) region genes (Campbell et al. 1984). This trans-activator is packaged into the virion and, upon infection of the host cell, trans-activates the HSV IE genes not through direct DNA binding (Marsden et al. 1987) but, rather, through interaction with cellular intermediates (Kristie and Roizman 1987; McKnight et al. 1987; O'Hare and Goding 1988; Preston et al. 1988; Triezenberg et al. 1988b). The domain within VP16 that is responsible for trans-activation is highly negatively charged and thus is an excellent example of an acidic trans-activation domain (Triezenberg et al. 1988a). VP16 can activate HSV IE gene expression through different sequence motifs,

Figure 4. Trans-activation properties of GAL4 on the $\beta$-globin and $\mathrm{U} 2$ promoters. (Left) $\mathrm{p} \beta$ enh $^{-}$(lanes 1 and 2) and $\mathrm{p} \beta \mathrm{UAS}_{\mathrm{G}} /$ -143 (lanes 3-5), a $\mathrm{p} \beta \mathrm{e}^{-}$derivative with the $\mathrm{UAS}_{\mathrm{G}}$ inserted $143 \mathrm{bp}$ upstream of the transcriptional start site, were transfected into HeLa cells, with or without a second plasmid expressing the DNA-binding domain of GAL4 (pAG147) or the DNA-binding domain and trans-activation domain II of GAL4 (pAG236) (Kakidani and Ptashne 1988). $\pi$ SVHP $\alpha 2$ was included in each transfection as an internal reference. Cytoplasmic RNA was analyzed by RNase protection mapping with the $\beta 350$ and $\alpha 132$ probes. Bands corresponding to correctly initiated $\beta$ globin $(\beta)$ and $\alpha$-globin $(\alpha)$ RNA are indicated. (Right) pU2/-198 (lanes 6 and 7) and pU2UAS $/$ / 198 , a pU2/-198 derivative with the $\mathrm{UAS}_{\mathrm{G}}$ inserted $198 \mathrm{bp}$ upstream of the transcriptional start site (lanes 8-10), were transfected into HeLa cells, with or without a second plasmid expressing the GAL4 protein derivatives described above, as indicated above the lanes. (Lane 11) pU2/-247 carrying the wild-type U2 promoter was used for transfection. The plasmid $\pi S V H P \alpha 2$ was included in each transfection as an internal reference. Cytoplasmic RNA was analyzed by RNase protection mapping with the U2 A probe and the $\alpha 98$ probe. Bands corresponding to correctly initiated U2 (U2 5') and $\alpha$-globin $(\alpha)$ transcripts are indicated. Bands corresponding to readthrough RNAs initiated at cryptic promoters within the vectors are labeled as such. The upper right portion, showing the readthrough transcripts, is from a long exposure of the same gel shown below. 
one of which includes the TAATGARAT motif (Kristie and Roizman 1984; Preston et al. 1984; Triezenberg et al. 1988b|. The TAATGARAT motif is frequently associated with overlapping octamer motifs (Pruijn et al. 1986; Gerster and Roeder 1988; O'Hare and Goding 1988). Moreover, although considerably diverged in sequence from the octamer motif, the TAATGARAT motif itself can bind directly to the HeLa cell octamer binding protein Oct-1 (OBP100) (Baumruker et al. 1988), and VP16 can trans-activate promoters containing the octamer motif (O'Hare and Goding 1988). Therefore, we tested whether coexpression of VP16 could activate the otherwise inactive $\beta$-globin expression construct $6 \times \mathrm{B} 20 d p m 2$, containing the wild-type octamer motif.

Figure 5 shows the result of this experiment. Except

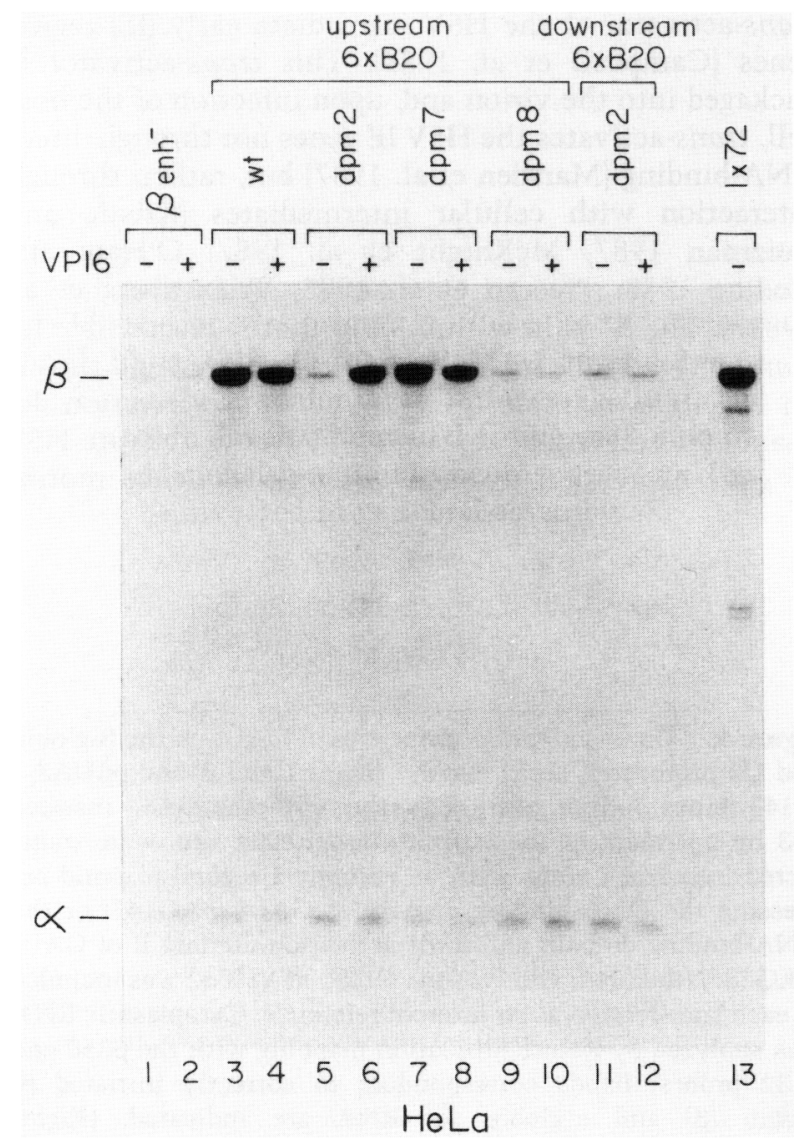

Figure 5. Activation of the $\beta$-globin promoter by the octamer motif in the presence of the VP16 protein in HeLa cells. p $\beta \mathrm{e}^{-}$ derivatives were transfected into HeLa cells, either with (lanes labeled + ) or without (lanes labeled -1 the plasmid pMSVP16 1D3 (Triesenberg et al. 1988a), which directs expression of the HSV trans-activator VP16. The $\beta$-globin constructs used in the transfections are identical to those used in Fig. 2 and their structure is indicated above the lanes. (Lane 13) $\mathrm{p} \beta 1 \times 72^{-}$was used for comparison. The plasmid $\pi S V H S \alpha 2$ (Treisman et al. 1983), which differs from $\pi$ SVHP $\alpha 2$ by the absence of the SV40 enhancer, was included in each transfection as an internal reference. Cytoplasmic RNA was analyzed by RNase protection mapping with the $\beta 350$ and $\alpha 132$ probes. Bands are labeled as in Fig. 2. for the normally inactive $d p m 2$ mutant, coexpression of VP16 did not change the activities of the different $\beta$ globin constructs. In contrast, the $6 \times \mathrm{B} 20 \mathrm{dpm} 2$ construct is activated $>10$-fold by coexpression of VP16 (cf. lanes 5 and 6; see Table 1). Curiously, this activation is position dependent, because when the $6 \times \mathrm{B} 20 \mathrm{dpm} 2$ oligomers are positioned $2.2 \mathrm{~kb}$ downstream of the $\beta$ globin promoter (see Fig. 1C), VP16 expression has little or no effect on $\beta$-globin expression (cf. lanes 11 and 12; Table 1). Thus, the acidic trans-activation domain of VP16 can apparently convert an otherwise inactive octamer motif into a $\beta$-globin activator element but is not sufficient to confer enhancer function over large distances (see Discussion).

\section{Discussion}

We made use of the SV40 B element to elucidate how a single cis-acting element, the octamer motif, can activate both cell-specific genes and ubiquitously expressed genes. The B element proved ideal to address this question, because it contains overlapping sph and octamer motifs, and the activities associated with these two types of motifs can be defined and separated by different sets of double point mutations. Thus, we could design a set of four matched wild-type and mutant oligomerized B-element constructs with either both, one, or none of the octamer and sph motif activities. This provided a built-in internal control, because for each promoter and cell line combination, at least one of the B element constructs activated expression. Thus, any observed failure of the B element to activate expression was a direct consequence of the specific point mutations and not the result of a more general context effect.

In summary, our results show that the sph motifs can activate the $\beta$-globin promoter in HeLa cells, but these motifs, along with other SV40 enhancer elements, cannot activate the $\mathrm{U} 2$ promoter. In contrast, the octamer motif can activate the U2 promoter in HeLa cells (and B cells) but can activate the $\beta$-globin promoter only in B cells or only if the VP16 trans-activator is present in HeLa cells. Although our experiments do not identify directly the trans-acting factors responsible for these different activities, the correlation between the expression patterns of the ubiquitous Oct-1 octamer binding protein (see Sturm et al. 1988) and the lymphoid-specific Oct-2 octamer binding protein (see Clerc et al. 1988) suggests that these two factors are, respectively, responsible for the ubiquitous snRNA activation and the $B$ cell-specific $\beta$-globin activation by the octamer motif.

\section{A model for octamer motif function in different promoters and cell types}

The different patterns of transcriptional activation by the octamer motif within the SV40 enhancer B element suggest the model presented in Figure 6. This figure shows a series of cartoons depicting hypothetical transcription complexes that form in B cells or HeLa cells, on either the $\beta$-globin or U2 snRNA promoter carrying the SV40 B element. For simplicity, only one copy of the 
SV40 B element is shown, and the RNA polymerase II complex itself is not represented. The pattern of $U 1$ and U2 transcription sensitivity to $\alpha$-amanitin demonstrates that these genes are transcribed by an RNA polymerase containing the large subunit of RNA polymerase II (Frederiksen et al. 1978; Gram Jensen et al. 1979|. It should be noted, however, that the RNA polymerase II complex that transcribes snRNA genes may differ slightly from the RNA polymerase II that transcribes mRNA-encoding genes. For example, it may lack an elongation factor (Hernandez and Lucito 1988).

Figure 6A shows the transcription complex formed on the $\beta$-globin promoter in B cells. A TATA box complex is shown bound close to the cap site, and the B cell-specific Oct- 2 factor is bound to the B element. This factor activates expression of mRNA genes and may therefore be a trans-activator of the GAL4 class. For this reason, the trans-activation domain of Oct-2 is shown negatively charged. Oct- 2 is also shown interacting directly with the TATA complex because recent evidence suggests that in vitro, GAL4 can interact with the mammalian TATA factor TFIID on a promoter containing a GAL4-binding site inserted upstream of the TATA box (Horikoshi et al. 1988). The inactivity of the sph motifs in B cells suggests that the sph transcription factor is absent or inactive in this cell line.

In Figure 6B, the transcription complex formed in HeLa cells on the same $\beta$-globin promoter is shown. In this case, the sph motifs are active. One sph-binding factor is shown bound to each sph motif, and together the two proteins form an activation domain of the GAL4 type, able to interact with the TATA box complex. Both motifs are shown occupied, because an sph enhanson needs to be juxtaposed to a second enhanson to be functional (Ondek et al. 1988). In this respect, the sph enhansons differ from the B-cell-specific octamer enhanson, which can function autonomously. That the TATA box complex is unchanged in Hela cells, as compared to $B$ cells, is suggested by the observation that the $\beta$-globin promoter construct containing the $\mathrm{UAS}_{\mathrm{G}}$ is stimulated by GAL4 in both HeLa (Fig. 4) and B cells (not shown). The different $B$ cell and HeLa cell activities of the B element illustrate how a very small element can contain two different cell-type-specific activities.

The putative transcription complex formed on the $\mathrm{U} 2$ snRNA promoter is depicted in Figure 6C. Like all RNA polymerase II snRNA promoters, the U2 promoter does not have a TATA box. Instead, it contains a proximal element essential for transcription (for review, see Dahlberg and Lund 1988) located 43-59 bp upstream of the cap site (Hernandez and Lucito 1988). The proximal element probably binds a different factor(s) than the TATA box, and we refer to this protein(s) as the snRNA proximal complex. Activation of the U2 proximal complex occurs by a different mechanism than activation of the TATA complex of mRNA promoters, because it is not stimulated by the SV40 A and C elements, the sph motifs, nor the GAL4 trans-activator, all of which stimulate the $\beta$-globin promoter. The U2 promoter is, however, stimulated by the octamer motif, that suggests that
A

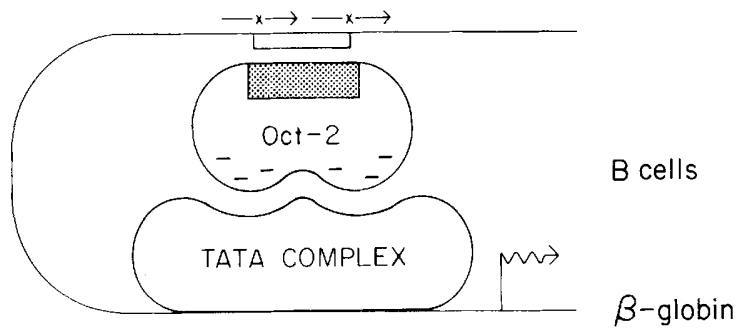

B

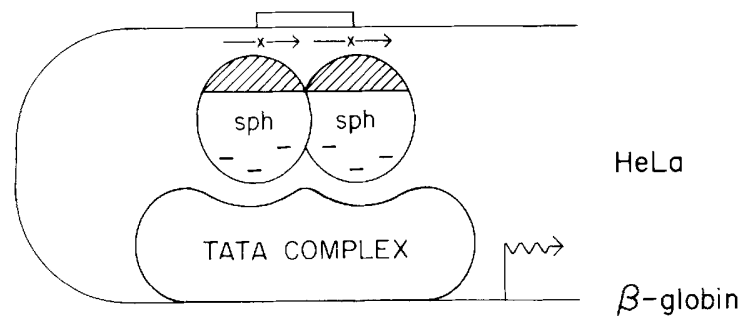

C

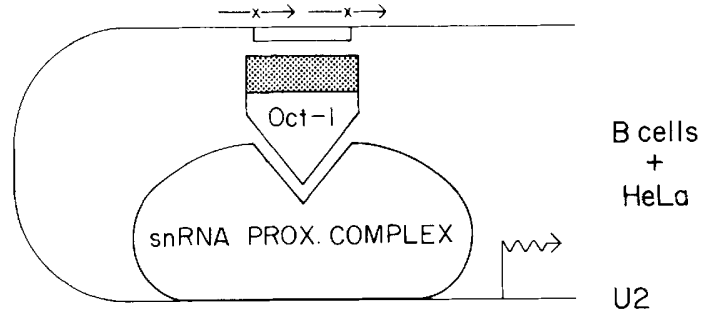

D



Figure 6. Model for activation of the $\beta$-globin and U2 promoters by the octamer and sph motifs. Hypothetical complexes formed on the $\beta$-globin and U2 promoters in B cells and in HeLa cells are shown. The DNA is represented by a thin line, the sph motifs are symbolized by arrows, and the octamer motif is indicated by an open box. For simplicity, only one wild-type B20 repeat of the synthetic enhancer is shown. (In $D$, B20 wildtype is replaced by $\mathrm{B} 20 / d p m 2$, i.e., there are no functional sph motifs.) The start site of transcription is depicted by a wavy arrow. The DNA is looped and shown binding a proximal promoter complex (TATA complex or snRNA proximal complex) and a distal trans-activator. Successful protein-protein interactions between the trans-activator and the proximal complex result in an increased rate of transcription initiation. The octamer motif DNA binding domains are stippled and the sph motif DNA binding domain is shown striped. The trans-activation domains of the GAL4-type trans-activators are shown as acidic domains. Oct- 1 and Oct- 2 are likely candidates for the trans-activation factors binding to the octamer motif (for further details, see text). 
it is the ubiquitous Oct-1 protein which is involved in snRNA transcription.

Although the octamer motif cannot activate the $\beta$ globin promoter in HeLa cells, coexpression of the HSV VP16 protein converts the octamer motif into a mRNA promoter-activating element. In Figure $6 \mathrm{D}$, a model of the transcription complex formed in HeLa cells in the presence of VP16 is shown. Oct-1, normally unable to activate the TATA complex of the $\beta$-globin promoter, is shown bound to the octamer motif and interacting with VP16, which in this model converts the Oct-1 protein into a GAL4 class trans-activator by providing it with an acidic domain. VP16 thus effectively plays the role of an adaptor between Oct-1 and the TATA complex. VP16 indeed contains an acidic domain that is required for trans-activation (Triezenberg et al. 1988a), and a hybrid protein consisting of the GAL4 DNA binding domain fused to the VP16 acidic domain is capable of activating a TATA box promoter in which GAL4-binding sites have been inserted (Sadowski et al. 1988). In addition, the formation in vitro of an octamer binding complex containing Oct-1, VP16, and a third, unidentified cellular protein has recently been demonstrated /Gerster and Roeder 1988). Thus, VP16 is an example of a nonDNA-binding protein that can switch a promoter from an inactive to an active state.

We were surprised to find that in the presence of VP16, the octamer motif activated $\beta$-globin transcription only at a short distance from the promoter, because the VP16/GAL4 hybrid protein can activate expression from a distance of $\sim 2 \mathrm{~kb}$ (Sadowski et al. 1988). This position dependence may reflect a property of the octamer enhanson which, in contrast to other enhansons that function in pairs (Ondek et al. 1988), can function without being closely juxtaposed to a second enhanson. Indeed, the synthetic enhancer $6 \times 820 d p m 2$, in which only the octamer motif is active, was quite sensitive to distance in all the constructs and cell lines tested, including the U2 promoter. Alternatively, interaction of VP16 with Oct-1 may weaken the affinity of Oct-1 for the octamer motif, rendering activation over long distances impossible. We have shown previously that Oct-1 (OBP100) has an affinity, albeit weak, for the TAATGARAT motif present in the HSV early promoters (Baumruker et al. 1988). We suggested that VP16 may effectively reprogram the binding specificity of Oct-1 so as to secure this cellular transcription factor for HSV transcription. In this respect, it will be of interest to determine whether the TAATGARAT motif can enhance expression of the $\beta$-globin gene at a distance in the presence of VP16.

The model presented in Figure 6 is consistent with all of our data. Whereas the specificity of transcription is generally thought to be conferred by upstream cis-acting elements (for review, see Maniatis et al. 1987; Ptashne 19881, the model presents the octamer motif as an example where specificity of transcription is conferred by the proximal element. In this context, the observation that different TATA boxes all respond similarly to induction mediated through the heat shock element or the
SV40 enhancer, but fall into two classes-responsive and nonresponsive-when tested for E1A activation, suggests that regulation of expression by proximal elements is more general than usually thought (Simon et al. 1988). However, if the Oct-1 protein cannot activate the TATA complex, how can the octamer motif be involved in ubiquitous activation of the histone $\mathrm{H} 2 \mathrm{~B}$ promoter? In this promoter, the octamer motif is uniquely placed adjacent to the TATA box and confers a cell-cycle-regulated activation of transcription (LaBella et al. 1988). Because there is no evidence that the DNA-binding activity of Oct-1 is cell cycle regulated, it is possible that a cell-cycle-regulated factor interacts with the juxtaposed Oct-1 and TATA-binding proteins, resulting in periodic activation of the promoter. This suggestion implies that in the context of the $\mathrm{H} 2 \mathrm{~B}$ promoter, the close proximity of the octamer motif and the TATA box is required for its function (see also LaBella et al. 1988).

The model is also consistent with previous reports demonstrating that the Ul enhancer cannot activate transcription from the SV40 early promoter (Ciliberto et al. 1987; Dahlberg and Schenborn 1988), and with studies on the mechanism of U1 and U2 $3^{\prime}$ end formation. These showed that $3^{\prime}$ end formation not only requires the snRNA $3^{\prime}$ box but also signals located in the $5^{\prime}$-flanking sequence of the genes (Hernandez and Weiner 1986; Neuman de Vegvar et al. 1986). An extensive mutagenesis of the $\mathrm{U} 2$ promoter region then demonstrated that the $5^{\prime}$ signals required for $3^{\prime}$ end formation coincide with promoter elements, suggesting that the $\mathrm{U} 2$ promoter directs the formation of a specialized transcription complex able to recognize the $3^{\prime}$ box as a termination signal (Hernandez and Lucito 1988). In addition, Neuman de Vegvar et al. (1986) have shown that when the $3^{\prime}$ box of the human Ul gene is debilitated by mutations, short RNAs with $3^{\prime}$ ends mapping upstream of cryptic $3^{\prime}$ boxes in the 3 '-flanking sequence are generated. This suggests that in contrast to the transcription complexes formed on mRNA promoters, the transcription complexes formed on snRNA promoters do not have the capacity to transcribe through long distances of DNA.

Examination of the different activities of the octamer motif reveals that at least one mechanism exists to activate polymerase II gene expression that is different from the general mechanism involving acidic domains and exemplified by the GAL4 protein. Why? The answer may lie in the fact that snRNA genes are extremely active transcription units, and the $\mathrm{U} 1$ and $\mathrm{U} 2$ snRNA genes must be transcribed, on average, once every $2 \mathrm{sec}$ to account for the synthesis of the complement of snRNPs required during one HeLa cell generation (Ares et al. 1985). Thus, the snRNA promoter may use a separate class of transcriptional complex to prevent 'squelching.' Squelching is a phenomenon of general inhibition of transcription that occurs when a very strong GAL4 class activator, such as a hybrid protein containing the GAL4 DNA-binding domain and the VP16 acidic domain, is expressed in a cell (Gill and Ptashne 1988; Sadowski et al. 1988; see also Ptashne 1988). 
Squelching may occur because the strong activator interacts with a cellular transcription factor /such as the TATA-box-binding factor) independently of DNA binding, effectively depleting the cell of a limiting transcription factor (Ptashne 1988). Thus, transcription units such as snRNA genes, which are always highly expressed in growing cells, may employ their own transactivation mechanism to avoid competition with mRNA promoters. Other highly expressed transcription units, such as the ribosomal genes, may have solved this problem by using another polymerase (i.e., RNA polymerase I), which may also not respond to the GAL4 type of trans-activators.

\section{Methods}

\section{$\beta$-Globin constructs}

The plasmids $\mathrm{p} \beta \mathrm{e}^{-}$and $\mathrm{p} \beta 1 \times 72^{-}$(Ondek et al. 1987), $\mathrm{p} \beta 6 \times \mathrm{sphI} / \mathrm{sphI}^{+}$and $\mathrm{p} \beta 6 \mathrm{xsphII} / \mathrm{sphII}^{+}$(Ondek et al. 1988), and p $\beta$ Igh - (Sturm et al. 1987) have been described previously. The synthetic enhancers B20dpm 7 and B20dpm 8 were constructed, as described previously (Ondek et al. 1988), by self-ligation of double-stranded oligonucleotides with complementary $3^{\prime}$ overhangs. Fragments containing six copies of the oligonucleotides were isolated and inserted into the unique downstream SphI site of $\mathrm{p} \beta \mathrm{e}^{-}$(Ondek et al. 1987; see Fig. 1c), after removal of the 3 ' overhangs. The resulting constructs had synthetic enhancers inserted in the minus orientation, as indicated in Figure 1C, except the B20dpm 16 construct, which is in the plus orientation. The synthetic enhancers B20 and B20dpm 2 are identical to the previously described (Ondek et al. 1988) sphII/sphI and sphII/MsphI synthetic enhancers, respectively. In these original constructs, however, the synthetic enhancers were in the plus orientation and therefore were inverted to match the other synthetic enhancer constructs. This was done by excising a PstIHindIII fragment containing the synthetic B20 or B20dpm 2 enhancers and reinserting flush-ended fragments into the SphIcleaved $\mathrm{pBe}^{-}$vector by blunt-end ligation, to give the constructs $\mathrm{p} \beta 6 \times \mathrm{B} 20^{-}$and $\mathrm{p} \beta 6 \times \mathrm{B} 20 \mathrm{dpm} 2^{-}$. The proximal $\mathrm{p} \beta 6 \times \mathrm{B} 20^{+/}-143, \mathrm{p} \beta 6 \times \mathrm{B} 20 d p m 2^{+/}-143, \mathrm{p} \beta 6 \times \mathrm{B}^{2} 2 d p m 7^{+/}$ -143 , and $\mathrm{p} \beta 6 \times \mathrm{B} 20 \mathrm{dpm} 8^{+} /-143$ constructs were prepared by inserting the PstI-HindIII synthetic enhancer fragments excised from original downstream constructs into the $S \mathrm{maI}$ site of

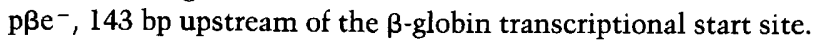
$\mathrm{p} \beta 1 \times 72+/-143$ was constructed by inserting the 100 -bp BamHI-PvuII fragment derived from pAO (Zenke et al. 1986) into the $S m a I$ site of $\mathrm{pBe}^{-} \cdot \mathrm{p} \beta U A S_{\mathrm{G}} /-143$ was constructed by inserting a filled-in BgIII fragment derived from pRY24 lobtained from $M$. Ptashne) into the $\mathrm{p} \beta \mathrm{e}^{-}$SmaI site. This fragment corresponds to the $365-\mathrm{bp}$ Sau3AI-DdeI fragment from the GAL1-GAL10 promoter region fitted with BgIII linkers.

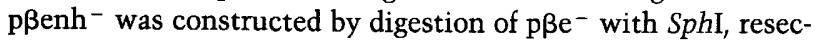
tion of the $3^{\prime}$ overhangs, and religation (Ondek et al. 1987). Some of the constructs have small changes from expected structures. These include insertions or deletions up to $2 \mathrm{bp}$ at the junction upon cloning and $\mathrm{G} \rightarrow \mathrm{A}$ transition at the third nucleotide of the sphII motif in the first copy of $6 \times \mathrm{B} 20 \mathrm{dpm} 8$ construct.

\section{U2 constructs}

pU2/-198, pU2/-247, pU26×A21/-198, pU26× C17/-198, pU26 $\times$ B17/ -198 have been described previously (Hernandez and Lucito 1988). pU26 $\times$ B20/-198, pU26 × B20dpm2/-198,
pU $26 \times \mathrm{B} 20 d p m 7 /-198$, and pU26 $\times$ B $20 d p m 8 /-198$ were constructed from the pU2/ -247 plasmid (Hernandez and Lucito 1988 ) by replacing the EcoRI-SmaI U2 promoter fragment extending from -247 to -198 upstream of the U2 transcriptional with the synthetic enhancers fragments described above. In these constructs, the synthetic enhancers are in the plus orientation, relative to the transcriptional direction of the $\mathrm{U} 2$ promoter. pU2UAS $\mathrm{G}_{\mathrm{G}} / 198$ was constructed by replacing the EcoRI-SmaI U2 promoter fragment with the $\mathrm{UAS}_{\mathrm{G}} B g I I$ fragment described above.

The plasmids pAG147 and pAG236 were kindly sent by G. Toukatly and $M$. Ptashne and are described in Kakidani and Ptashne (1988). The $\alpha$-globin plasmids with $(\pi S V H P \alpha 2)$ or without $(\pi S V H S \alpha 2)$ the SV40 enhancer are described in Treisman et al. (1983), and pMSVP16 1D3 was obtained from S. McKnight (Triesenberg et al. 1988a).

\section{Transfections}

NS-1 B cells were transfected by the DEAE-dextran method followed by chloroquine treatment, as described (Ondek et al. 1987), with $4 \mu \mathrm{g}$ of the different test plasmids ( $\beta$-globin and U2 plasmids) and $0.2 \mu \mathrm{g}$ of the $\pi S V H P \alpha 2$ internal reference plasmid. HeLa cells were transfected by the calcium-phosphate coprecipitation procedure, as described (Ondek et al. 1987), except that the precipitates were left on the cells for $24 \mathrm{hr}$, and were washed once with phosphate-buffered saline (PBS) and once with PBS containing $1 \mathrm{~mm}$ EGTA. The cells were incubated for an additional $24 \mathrm{hr}$ before harvesting. Two micrograms of the $\beta$-globin test plasmids were transfected together with $0.25 \mu \mathrm{g}$ of $\pi \mathrm{SVHP} \alpha 2(2 \mu \mathrm{g}$ of $\pi \mathrm{SVHS} \alpha 2$ in Fig. 5), and $4 \mu \mathrm{g}$ of the U2 test plasmids were transfected together with $0.1 \mu \mathrm{g}$ of $\pi \mathrm{SVHP} \alpha 2$. Where indicated, $4 \mu \mathrm{g}$ of pAG147 or pAG236, and $2 \mu \mathrm{g}$ of pMSVP16 $1 \mathrm{D} 3$ were included. A total of $10 \mu \mathrm{g}$ of DNA (with pUC119 as a carrier) was used for a $60-\mathrm{mm}$ dish.

\section{RNA analysis}

Cytoplasmic RNA was prepared from transfected cells by the NP-40 lysis method, as described (Hernandez and Lucito 1988), and was analyzed by the RNase protection method (Zinn et al. 1983), with either RNase T1 alone (transfections with U2 test plasmids) or with a mixture of RNase A and T1 (transfections with the $\beta$-globin plasmids). The $\alpha 98$ and $\alpha 132$ riboprobes map transcripts derived from the $\alpha$-globin reference gene and are protected over 98 and 132 nucleotides, respectively, by correctly initiated $\alpha$-globin RNA. The $\beta 350$ riboprobe maps transcripts derived from the test $\beta$-globin gene and is protected over 350 nucleotides by correctly initiated $\beta$-globin RNA. The U2 A probe maps transcripts derived from the hybrid $U 2$ gene and is protected over 135 nucleotides by RNA correctly initiated at the $U 2$ cap site. The results were quantitated by excising relevant bands from the gels and measuring their radioactivity by scintillation counting or in some cases by densitometric analysis of the autoradiograms.

\section{Acknowledgments}

We thank G. Toukatly and M. Ptashne for expeditiously sending us the GAL4-expressing plasmids, T. Baumruker, M. Ptashne, I. Sodowski, and R. Sturm for helpful discussions, and M. Gilman, P. Reinagel, and B. Stillman for comments on the manuscript. We also thank R. Lucito for technical assistance, M. Iacovacci and M. Zoller for synthesis of oligonucleotides, J. 
Duffy and D. Green for artwork and photography, and M. Goodwin and J. Liebowitz for secretarial assistance. W.H. is a Rita Allen Foundation scholar. This work was supported by a National Science Foundation grant (DMB-8718903) to W.H. and a National Institutes of Health grant (RO1 GM38810-01) to N.H.

\section{Note added in proof}

Fromental et al. 1988 (Cell 54: 943-953) recently have discovered the autonomous B cell-specific enhanson activity of the SV40 octamer motif.

\section{References}

Ach, R.A. and A.M. Weiner. 1987. The highly conserved U small nuclear RNA 3' end formation signal is quite tolerant to mutation. Mol. Cell. Biol. 7: 2070-2079.

Ares, M., Jr., M. Mangin, and A.M. Weiner. 1985. Orientationdependent transcriptional activator upstream of a human U2 snRNA gene. Mol. Cell. Biol. 5: 1560-1570.

Ares, M., Jr., J.-S. Chung, L. Giglio, and A.M. Weiner. 1987. Distinct factors with Spl and NF-A specificities bind to adjacent functional elements of the human U2 snRNA gene enhancer. Genes Dev. 1: 808-817.

Baumruker, T., R. Sturm, and W. Herr. 1988. OBP100 binds remarkably degenerate octamer motifs through specific interactions with flanking sequences. Genes Dev. 2: 1400-1413.

Brent, R. and M. Ptashne. 1985. A eucaryotic transcriptional activator bearing the DNA specificity of a procaryotic repressor. Cell 43: 729-736.

Campbell, M.E.M., J.W. Palfreyman, and C.M. Preston. 1984. Purification of herpes simplex virus DNA sequences which encode a trans-acting polypeptide responsible for stimulation of immediate early transcription. I. Mol. Biol. 180: 119.

Ciliberto, G., R. Buckland, R. Cortese, and L. Philipson. 1985. Transcription signals in embryonic Xenopus laevis Ul RNA genes. EMBO /. 4: 1537-1543.

Ciliberto, G., N. Dathan, R. Frank, L. Philipson, and I.W. Mattaj. 1986. Formation of the 3' end of U snRNAs requires at least three sequence elements. EMBO /. 5: 2931-2937.

Ciliberto, G., F.Palla, G. Tebb, I.W. Mattaj, and L. Philipson. 1987. Properties of a Ul RNA enhancer-like sequence. $\mathrm{Nu}$ cleic Acids Res. 15: 2403-2416.

Clerc, R.G., L.M. Corcoran, J.H. LeBowitz, D. Baltimore, and P. Sharp. 1988. The B-cell specific Oct-2 protein contains Poubox and homeobox-type domains. Genes Dev. 2: 15701581.

Dahlberg, J. and E. Lund. 1988. The genes and transcription of the major small nuclear RNAs. In Structure and function of major and minor small nuclear ribonucleoprotein particles (ed. M. Birnstiel), pp. 38-70. Springer Verlag, Heidelberg.

Dahlberg, J.E. and E.T. Schenborn. 1988. The human U1 snRNA promoter and enhancer do not direct synthesis of messenger RNA. Nucleic Acids Res. 16: 5827-5840.

Davidson, I., C. Fromental, P. Augereau, A. Wildeman, M. Zenke, and P. Chambon. 1986. Cell-type specific protein binding to the enhancer of simian virus 40 in nuclear extracts. Nature 323: $544-548$.

De Villiers, J. and W. Schaffner. 1981. A small segment of polyoma virus DNA enhances the expression of a cloned $\beta$ globin gene over a distance of 1400 base pairs. Nucleic Acids Res. 9:6251-6264.

Falkner, F.G. and H.G. Zachau. 1984. Correct transcription of an immunoglobulin $\kappa$ gene requires an upstream fragment containing conserved sequence elements. Nature 310: $71-$ 74.

Falkner, F.G., R. Mocikat, and H.G. Zachau. 1986. Sequences closely related to an immunoglobulin gene promoter/enhancer element occur also upstream of other eukaryotic and of prokaryotic genes. Nucleic Acids Res. 14: 8819-8827.

Fischer, J.A., E. Giniger, T. Maniatis, and M. Ptashne. 1988. GAL4 activates transcription in Drosophila. Nature 332: $853-856$.

Fletcher, C., N. Heintz, and R.G. Roeder. 1987. Purification and characterization of OTF-1, a transcription factor regulating cell cycle expression of a human histone $\mathrm{H} 2 \mathrm{~b}$ gene. Cell 51: 773-781.

Frederiksen, S., P. Hellung-Larsen, and E. Gram Jensen. 1978. The differential inhibitory effect of $\alpha$-amanitin on the synthesis of low molecular weight RNA components in BHK cells. FEBS Lett. 87: 227-231.

Gerster, T. and R.G. Roeder. 1988. A herpesvirus trans-activating protein interacts with transcription factor OTF-1 and other cellular proteins. Proc. Natl. Acad. Sci. 85: 63476351.

Gerster, T., P. Matthias, M. Thali, J. Jiricny, and W. Schaffner. 1987. Cell type-specificity elements of the immunoglobulin heavy chain gene enhancer. EMBO J. 6: 1323-1330.

Gill, G. and M. Ptashne. 1988. Negative effect of the transcriptional activator GAL4. Nature 334: 721-724.

Gram Jensen, E., P. Hellung-Larsen, and S. Frederiksen. 1979. Synthesis of low molecular weight RNA components A, C, and $\mathrm{D}$ by polymerase II in $\alpha$-amanitin resistant hamster cells. Nucleic Acids Res. 6: 321-330.

Harvey, R.P., A.J. Robins, and J.R.E. Wells. 1982. Independently evolving chicken histone $\mathrm{H} 2 \mathrm{~B}$ genes: Identification of a ubiquitous H2B-specific 5' element. Nucleic Acids Res. 10: $7851-7863$.

Hernandez, N. 1985. Formation of the $3^{\prime}$ end of Ul snRNA is directed by a conserved sequence located downstream of the coding region. EMBO J. 4: 1827-1837.

Hernandez, N. and R. Lucito. 1988. Elements required for transcription initiation of the human U2 snRNA gene coincide with elements required for snRNA $3^{\prime}$ end formation. $E M B O$ J. 7: 3125-3134.

Hernandez, N. and A.M. Weiner. 1986. Formation of the $3^{\prime}$ end of Ul snRNA requires compatible snRNA promoter elements. Cell 47: 249-258.

Herr, W. and J. Clarke. 1986. The SV40 enhancer is composed of multiple functional elements that can compensate for one another. Cell 45: 461-470.

Hope, I.A. and K. Struhl. 1986. Functional dissection of a eucaryotic transcriptional activator protein, GCN4 of yeast. Cell 46: $885-894$.

Hope, I.A., S. Mahadevan, and K. Struhl. 1988. Structural and functional characterization of the short acidic transcriptional activation region of yeast GCN4 protein. Nature 333: $635-640$.

Horikoshi, M., M.F. Carey, H. Kakidani, and R.G. Roeder. 1988. Mechanism of action of yeast activator: Direct effect of GAL4 derivatives on mammalian TFIID-promoter interactions. Cell 54: 665-669.

Janson, L., C. Bark, and U. Pettersson. 1987. Identification of proteins interacting with the enhancer of human $\mathrm{U} 2$ small nuclear RNA genes. Nucleic Acids Res. 15: 4997-5016.

Kakidani, H. and M. Ptashne. 1988. GAL4 activates gene expression in mammalian cells. Cell 52: 161-167.

Keegan, L., G. Gill, and M. Ptashne. 1986. Separation of DNBA binding from the transcription-activating function of a eucaryotic regulatory protein. Science 231: 699-704. 
Kristie, T.M. and B. Roizman. 1984. Separation of sequences defining the basal expression from those conferring $\alpha$ gene recognition within the regulatory domains of herpes simplex virus $1 \alpha$ genes. Proc. Natl. Acad. Sci. 81: 4065-4069.

- 1987. Host cell proteins bind to the cis-acting site required for virion-mediated induction of herpes simplex virus $1 \alpha$ genes. Proc. Natl. Acad. Sci. 84: 71-75.

LaBella, F., H.L. Sive, R.G. Roeder, and N. Heintz. 1988. Cellcycle regulation of a human histone $\mathrm{H} 2 \mathrm{~b}$ gene is mediated by the H2b subtype-specific consensus element. Genes Dev. 2: $32-39$.

Landolfi, N.F., J.D. Capra, and P.W. Tucker. 1986. Interaction of cell-type-specific nuclear proteins with immunoglobulin $\mathrm{V}_{\mathrm{H}}$ promoter region sequences. Nature 323: 548-551.

Lech, K., K. Anderson, and R. Brent. 1988. DNA-bound Fos proteins activate transcription in yeast. Cell 52: 179-184.

Lenardo, M., J.W. Pierce, and D. Baltimore. 1987. Proteinbinding sites in Ig gene enhancers determine transcriptional activity and inducibility. Science 236: 1573-1577.

Ma, J. and M. Ptashne. 1987a. Deletion analysis of GAL4 defines two transcriptional activating segments. Cell 48: 847853.

. 1987b. A new class of yeast transcriptional activators. Cell 51: 113-119.

Ma, J., E. Przibilla, J. Hu, L. Bogorad, and M. Ptashne. 1988. Yeast activators stimulate plant gene expression. Nature 334: 631-633

Maniatis, T., S. Goodbourn, and J.A. Fischer. 1987. Regulation of inducible and tissue-specific gene expression. Nature 236: $1237-1245$.

Mangin, M., M. Ares, Jr., and A.M. Weiner. 1986. Human U2 small nuclear RNA genes contain an upstream enhancer. EMBO I. 5: 987-995.

Marsden, H.S., M.E.M. Cambpell, L. Haarr, M.C. Frame, D.S. Parris, M. Murphy, R.G. Hope, M.T. Muller, and C.M. Preston. 1987. The 65,000-Mr DNA binding and virion trans-inducing proteins of herpes simplex virus type 1. I. Virol. 61: 2428-2437.

Mattaj, I.W., S. Lienhard, J. Jiricny, and E.M. De Robertis. 1985. An enhancer-like sequence within the Xenopus U2 gene promoter facilitates the formation of stable transcription complexes. Nature 316: 163-167.

McKnight, J.L.C., T.M. Kristie, and B. Roizman. 1987. Binding of the virion protein mediating $\alpha$ gene induction in herpes simplex virus 1 -infected cells to its cis site requires cellular proteins. Proc. Natl. Acad. Sci. 84: 7061-7065.

Murphy, J.T., R. Burgess, J.E. Dahlberg, and E. Lund. 1982. Transcription of a gene for human U1 smalll nuclear RNA. Cell 29: 265-274.

Murphy, J.T., J.T. Skuzeski, E. Lund, T.H. Steinberg, R.R. Burgess, and J.E. Dahlberg. 1987. Functional elements of the human U1 promoter. J. Biol. Chem. 262: 1795-1803.

Neuman de Vegvar, H.E., E. Lund, and J.E. Dahlberg. 1986. 3 'end formation of U1 snRNA precursors is coupled to transcription from snRNA promoters. Cell 47: 259-266.

O'Hare, P. and C.R. Goding. 1988. Herpes simplex virus regulatory elements and the immunoglobulin octamer domain bind a common factor and are both targets for virion trans. activation. Cell 52: 435-445.

Ondek, B., L. Gloss, and W. Herr. 1988. The SV40 enhancer contains two distinct levels of organization. Nature 333: 40-45.

Ondek, B., A. Shepard, and W. Herr. 1987. Discrete elements within the SV40 enhancer region display different cell specific enhancer activities. EMBO \%. 6: 1017-1025.

O’Neill, E.A. and T.J. Kelly. 1988. Purification and character- ization of nuclear factor III (origin recognition protein C): a sequence-specific DNA binding protein required for efficient initiation of adenovirus DNA replication. $J$. Biol. Chem. 263: 931-937.

Parslow, T.G., D.L. Blair, W.J. Murphy, and D.K. Granner. 1984. Structure of the 5' ends of immunoglobulin genes: A novel conserved sequence. Proc. Natl. Acad. Sci. 81: 2650-2654.

Preston, C.M, M.G. Cordingley, and N.D. Stow. 1984. Analysis of DNA sequences which regulate the transcription of a herpex simplex virus immediate early gene. I. Virol. 50: $708-716$.

Preston, C.M., M.C. Frame, and M.E.M. Campbell. 1988. A complex formed between cell components and an HSV structural polypeptide binds to a viral immediate early gene regulatory DNA sequence. Cell 52: 425-434.

Pruijn, G.J.M., W. van Driel, and P.C. van der Vliet. 1986. Nuclear factor III, a novel sequence-specific DNA-binding protein from HeLa cells stimulating adenovirus DNA replication. Nature 322: 656-659.

Ptashne, M. 1988. How eucaryotic transcriptional activators work. Nature 335: 683-689.

Rosales, R., M. Vigneron, M. Macchi, I. Davidson, J.H. Xiao, and $\mathrm{P}$. Chambon. 1987. In vitro binding of cell-specific and ubiquitous nuclear proteins to the octamer motif of the SV40 enhancer and related motifs present in other promoters and enhancers. EMBO J. 6: 3015-3025.

Sadowski, I., J. Ma, S. Triezenberg, and M. Ptashne. 1988. GAL4-VP16 is an unusually potent transcriptional activator. Nature 335: 563-565.

Scheidereit, C., A. Heguy, and R.G. Roeder. 1987. Identification and purification of a human lymphoid-specific octamer binding protein (OTF-2) that activates transcription of an immunoglobulin promoter in vivo. Cell 51: 783-793.

Schirm, S., J. Jiricny, and W. Schaffner. 1987. The SV40 enhancer can be dissected into multiple segments, each with a different cell type specificity. Genes Dev. 1: 65-74.

Simon, M.S., T.M. Fisch, B.J. Benecke, J.R. Nevins, and N. Heintz. 1988. Definition of multiple, functionally distinct TATA elements, one of which is a target in the hsp70 promoter for E1A regulation. Cell 52: 723-729.

Singh, H., R. Sen, D. Baltimore, and P.A. Sharp. 1986. A nuclear factor that binds to a conserved sequence motif in transcriptional control elements of immunoglobulin genes. Nature 319: $154-158$.

Skuzeski, J.M., E. Lund, J.T. Murphy, T.H. Steinberg, R.R. Burgess, and J.E. Dahlberg. 1984. Synthesis of human U1 RNA. Identification of two regions of the promoter essential for transcription initiation at position +1 . I. Biol. Chem. 259: 8345-8352.

Staudt, L.M., H. Singh, R. Sen, T. Wirth, P.A. Sharp, and D. Baltimore. 1986. A lymphoid-specific protein binding to the octamer motif of immunoglobulin genes. Nature 323: 640643.

Struhl, K. 1988. The JUN oncoprotein, a vertebrate transcription factor, activates transcription in yeast. Nature 332: $649-650$.

Sturm, R.A., G. Das, and W. Herr. 1988. The ubiquitous octamer binding protein Oct- 1 contains a POU domain with a homeo subdomain. Genes Dev. 2: 1582-1599.

Sturm, R., T. Baumruker, B.R. Franza, Jr., and W. Herr. 1987. A $100-\mathrm{kD}$ HeLa cell octamer binding protein (OBPl00) interacts differently with two separate octamer-related sequences within the SV40 enhancer. Genes Dev. 1: 11471160 .

Treisman, R., M.R. Green, and T. Maniatis. 1983. Cis and trans activation of globin gene transcription in transient assays. 


\section{Tanaka et al.}

Proc. Natl. Acad. Sci. 80: 7428-7432.

Triezenberg, S.J., R.C. Kingsbury, and S.L. McKnight. 1988a. Functional dissection of VP16, the trans-activator of herpes simplex virus immediate early gene expression. Genes Dev. 2: 718-729.

Triezenberg, S.J., K.L. LaMarco, and S.L. McKnight. 1988b. Evidence of DNA: Protein interactions that mediate HSV-1 immediate early gene activation by VP16. Genes Dev. 2: 730742.

Webster, N., J.R. Jin, S. Green, M. Hollis, and P. Chambon. 1988. The yeast $\mathrm{UAS}_{\mathrm{G}}$ is a transcriptional enhancer in human HeLa cells in the presence of the GAL4 trans-activator. Cell 52: 169-178.

Wirth, T., L. Staudt, and D. Baltimore. 1987. An octamer oligonucleotide upstream of a TATA motif is sufficient for lymphoid-specific promoter activity. Nature 329: 174-178.

Yuo, C., M. Ares, Jr., and A.M. Weiner. 1985. Sequences required for $3^{\prime}$ end formation of human U2 small nuclear RNA. Cell 42: 193-202.

Zenke, M., T. Grundstrom, H. Matthes, M. Wintzerith, C. Schatz, A. Wildeman, and P. Chambon. 1986. Multiple sequence motifs are involved in SV40 enhancer function. EMBO I. 5: 387-397.

Zinn, K., D. DiMaio, and T. Maniatis. 1983. Identification of two distinct regulatory regions adjacent to the human $\beta$-interferon gene. Cell 34: 865-879. 


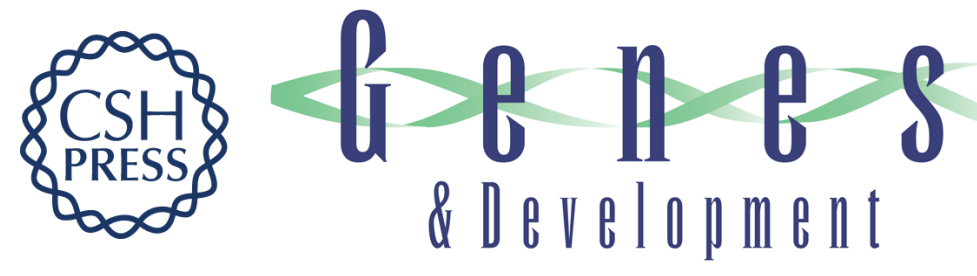

\section{Activation of the U2 snRNA promoter by the octamer motif defines a new class of RNA polymerase II enhancer elements.}

M Tanaka, U Grossniklaus, W Herr, et al.

Genes Dev. 1988, 2:

Access the most recent version at doi:10.1101/gad.2.12b.1764

References This article cites 78 articles, 24 of which can be accessed free at:

http://genesdev.cshlp.org/content/2/12b/1764.full.html\#ref-list-1

License

Email Alerting

Service

Receive free email alerts when new articles cite this article - sign up in the box at the top right corner of the article or click here.

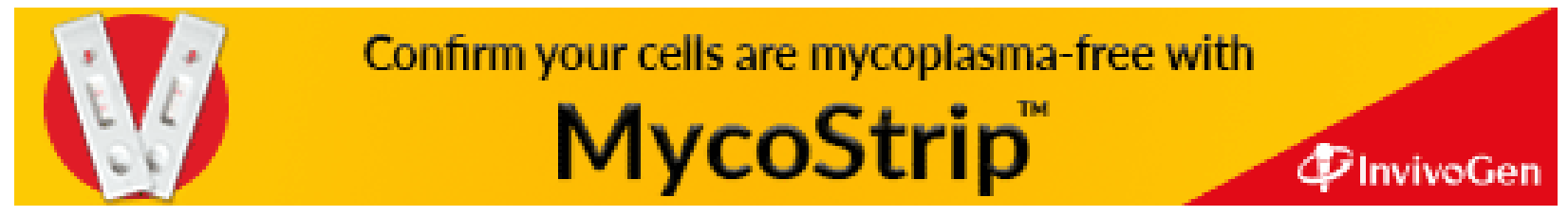

